\title{
AN OVERVIEW OF COASTAL LAND LOSS: WITH EMPHASIS ON THE SOUTHEASTERN UNITED STATES
}

Robert A. Morton

\author{
U.S. Geological Survey \\ Center for Coastal and Watershed Studies \\ St. Petersburg, FL 33701
}

OPEN FILE REPORT $03-337$ 


\section{SUMMARY}

In states bordering the Gulf of Mexico and the Atlantic Ocean, vast areas of coastal land have been destroyed since the mid 1800s as a result of natural processes and human activities. The physical factors that have the greatest influence on coastal land loss are reductions in sediment supply, relative sea level rise, and frequent storms, whereas the most important human activities are sediment excavation, river modification, and coastal construction. As a result of these agents and activities, coastal land loss is manifested most commonly as beach/bluff erosion and coastal submergence.

Wetlands are a unique class of coastal lands so they are considered independent of upland coastal areas. Wetlands are subjected to the same physical process and activities as other coastal lands, but they are also susceptible to deterioration as a result of biogeochemical processes. Failed reclamation projects and induced subsidence also contribute locally to wetland losses in the southeastern US.

\section{INTRODUCTION}

To many people, coastal land loss is synonymous with beach erosion. Coastal land loss includes beach erosion, but it is a much broader term because it also includes land losses along bluffs and losses of wetlands around interior bays and estuaries. The most important causes of coastal land loss (Fig. 1) are erosion, inadequate sediment supply to beaches and wetlands, and coastal submergence (relative rise in sea level). Any one of these causes may be responsible for most of the land loss at a particular site, or the land loss may be the result of several factors acting in concert (Fig. 2).

The primary causes of coastal land loss include both natural processes and human activities (Fig. 1). These primary causes determine where land will be lost whereas other factors, such as shoreline characteristics, control the rate of land loss. Some agents affecting land loss, such as wave energy, are common to all coasts, whereas other agents, such as vegetative cover, are only of local importance. In most coastal settings, the exact causes of land loss are uncertain, so it is necessary to evaluate all reasonable causes in order to predict what the coast might look like in the future and to understand how land loss will impact coastal communities.

Physical agents affect land losses in all coastal environments, but wetlands are also subject to biochemical reactions and altered water circulation patterns. Because wetlands are unique organic environments, the causes of their deterioration and destruction (Fig. 1) are discussed in a separate section.

This report represents a general overview of the primary causes and consequences of coastal land loss. Most of the examples and references are from states bordering the Gulf of Mexico and the Atlantic Ocean where the largest magnitudes and highest rates of coastal land losses in the United States are recorded (Dahl, 2000). The report serves as an introductory guide to the topics and literature on coastal land loss, and acts as a link to ongoing research being conducted by 
the U.S. Geological Survey.

\begin{tabular}{|c|c|}
\hline \multicolumn{2}{|c|}{ Primary Causes of Coastal Land Loss } \\
\hline \multicolumn{2}{|r|}{ Natural Processes } \\
\hline Agent & Examples \\
\hline Erosion & $\begin{array}{l}\text { waves and currents } \\
\text { storms } \\
\text { landslides }\end{array}$ \\
\hline Sediment Reduction & $\begin{array}{l}\text { climate change } \\
\text { stream avulsion } \\
\text { source depletion }\end{array}$ \\
\hline Submergence & $\begin{array}{l}\text { land subsidence } \\
\text { sea-level rise }\end{array}$ \\
\hline Wetland Deterioratio I & $\begin{array}{l}\text { herbivory } \\
\text { freezes } \\
\text { fires } \\
\text { saltwater intrusion }\end{array}$ \\
\hline \multicolumn{2}{|r|}{ Human Activities } \\
\hline Agent & Examples \\
\hline Transportation & boat wakes, altered water circulation \\
\hline Coastal Construction & $\begin{array}{l}\text { sediment deprivation (bluff retention) } \\
\text { coastal structures (jetties, groins, seawalls) }\end{array}$ \\
\hline River Modification & control and diversion (dams, levees) \\
\hline Fluid Extraction & water, oil, gas, sulfur \\
\hline Climate Alteration & $\begin{array}{l}\text { global warming and ocean expansion } \\
\text { increased frequency and intensity of storms }\end{array}$ \\
\hline Excavation & $\begin{array}{l}\text { dredging (canal, pipelines, drainage) } \\
\text { mineral extraction (sand, shell, heavy mins.) }\end{array}$ \\
\hline Wetland Destruction & $\begin{array}{l}\text { pollutant discharge } \\
\text { traffic } \\
\text { failed reclamation } \\
\text { burning }\end{array}$ \\
\hline
\end{tabular}

Figure 1. Common physical and anthropogenic causes of coastal land loss. 


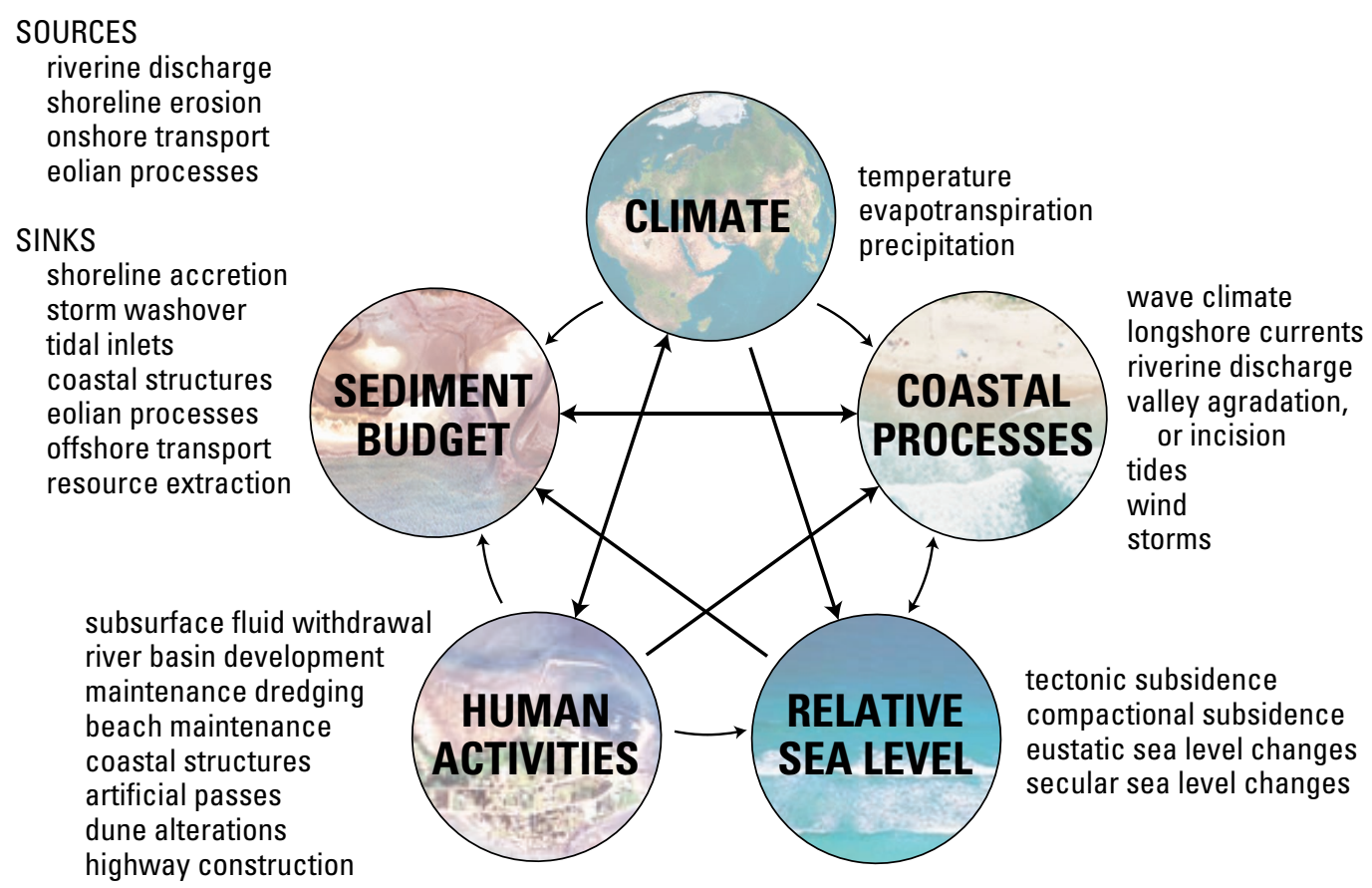

Figure 2. Interaction of factors that influence land loss. Modified from Morton (1977).

\section{THE PHYSICAL AGENTS OF LAND LOSS Waves, Currents, and Storm Surges}

Most exposed coasts lose land primarily as a result of erosion, the wearing away or removal of the land surface by mechanical, chemical, and biological agents. Landward retreat of the shore is commonly the result of this erosion. Coastal erosion is initiated by the movement of water in the form of high waves and strong currents. Breaking waves erode the coast by suspending sediment particles or dislodging rocks. Ice, chemical weathering, and mechanical abrasion also aid the erosion of some rocky headlands and sea cliffs. Beach cobbles and sand act as tools that repeatedly strike the rocks and gradually wear them down.

Powerful storms rapidly raise water levels and accelerate coastal currents causing the most rapid losses of land and perhaps most of the permanent land losses worldwide. Land loss during storms depends on many things, including distance from the storm center, storm-surge heights, wave characteristics, direction of storm movement, angle of wave approach, forward speed and duration of the storm, and tidal stage during storm landfall.

Storms that strike the coast at high tide, and especially at spring high tide, tend to cause more damage because the storm surge superimposed on the high tide causes greater flooding and overwash. In areas where the tide range is small, tidal stage is of little consequence to stormsurge heights, but it is often important where the tidal range is large. Land loss and property damage can increase when a peak storm surge coincides with high tide.

The most damaging coastal storms are either extratropical cyclones (winter storms) or tropical cyclones (hurricanes) that form around centers of low barometric pressure (Morton, 1988a). Winter storms derive their energy from the atmosphere, whereas the ocean is the principal 
energy source for summer hurricanes. Although the two storm systems are quite different, their influences on water bodies and nearshore environments are similar. Both generate high, steep waves and strong currents that introduce new sediment into the littoral system and redistribute pre-existing sediments over large areas of the shoreface and continental shelf. Although some coastal regions, like the middle Atlantic states, are ravaged by both winter storms and hurricanes, each region is usually affected most by one type of storm.

A combination of beach composition and storm characteristics determines how beaches are affected by storms. For example, retreat of bluffs and muddy shores occurs in an episodic, stepwise pattern without any seaward advancement between retreat events (Fig. 3). This is in contrast to sandy beaches that tend to at least partly recover after storms.

The sand beach is like a conveyor belt operating between the dunes and offshore sand bars. These two large reservoirs of sand and the beach constitute a sand-sharing system operated by the wind and waves. Storm waves erode the beach and dunes and transfer sand offshore; some of the sand is temporarily stored in offshore bars or on the shoreface and some is transported onto the shelf and deposited in relatively deep water where it is permanently lost from the littoral system. Non-storm waves tend to move the bar and shoreface sand back onto the beach where it is blown landward to form the dunes. Any interference with the onshore and offshore movement of sand, such as emplacement of coastal engineering structures, could promote land loss.

\section{Winter Storms (Extratropical Cyclones)}

Bluffs And Muddy Shores

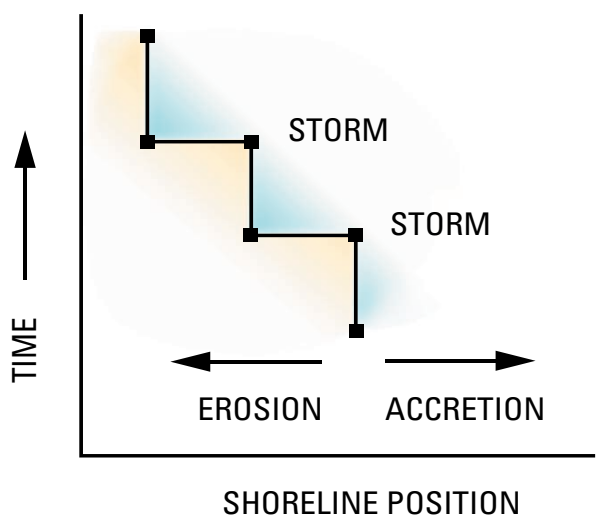

Sandy Beaches

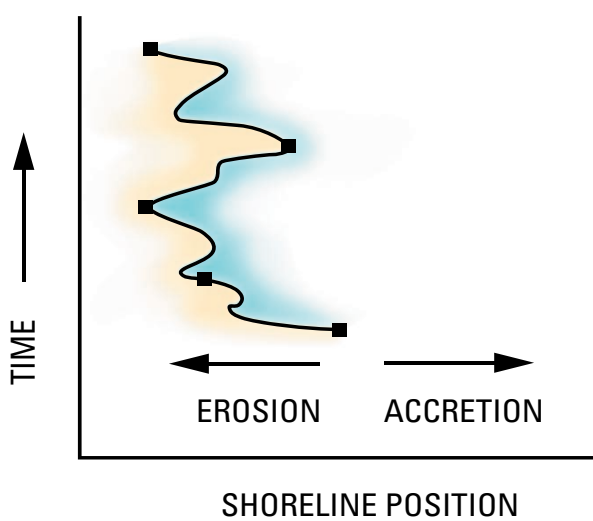

Figure 3. Movement of different types of shores through time. Bluffs abruptly retreat landward and then remain stable until the next erosion event. Sandy beaches typically retreat and advance in a cyclical pattern with the overall change being either retreat, as illustrated, or advance.

In North America, extratropical cyclones are large, mid- to high-latitude, winter storms associated with cold air masses that generally travel from west to east. Their strongest winds occur along fronts separating air masses, which vary greatly in temperature and humidity. These conditions produce several thousand extratropical disturbances each year (Riehl, 1979). However, only a few of those disturbances cause intense coastal storms with high winds and 
waves.

Winter storms driven by masses of cold Arctic air are responsible for significant land losses in the Gulf and Atlantic Coast regions where they are known as northers and northeasters, respectively (Roberts et al., 1987; Pilkey et al., 1989). Although hurricanes periodically ravage the Atlantic coastal states, winter storms typically account for more cumulative losses than hurricanes in this region. This is because intense winter storms occur frequently (several each year) and may last for several days, whereas hurricanes occur less frequently and only last for a few hours as they cross the coast. Extratropical winter storms also cause significant land losses around the Great Lakes, an area that is unaffected by hurricanes.

In the Gulf Coast region, frontal-related storms occur about every week to ten days from November to April. These storms act like pumps that cause rapid changes in water levels and associated wave erosion. Preceding passage of a cold front, low barometric pressure generates strong onshore winds that set water up along the coast, flooding open ocean and mainland beaches and exposing the shores to strong wave attack. As the front passes the coast, strong winds are directed offshore driving water onto the backbarrier flats and away from the ocean beaches. The frequent oscillation in water levels and waves erodes both sides of barrier islands as well as mainland and bay shores. Gulf Coast winter storms cause much less land loss or property damage than do hurricanes so they are not ranked or given names like severe northeasters of the Atlantic coast.

During the past 50 years, the Ash Wednesday Storm of March 1962 was probably the largest East Coast winter storm in terms of land loss and number of homes damaged or destroyed. This northeaster, which coincided with a spring tide, remained stationary for almost 36 hrs so that beach and barrier flooding lasted over 5 consecutive spring high tides (O'Brien and Johnson, 1963). The strong northeast winds, broad fetch, and high angle of wave approach caused record flooding and beach erosion down the eastern seaboard extending from New England to Florida. Most houses near the beach were destroyed by storm waves and washover unless a wide beach and high dunes protected them (Morton et al., 2003).

Another destructive northeaster struck the Atlantic coast in late October 1991 (Fig. 4a) and therefore is known as the Halloween storm. During the storm, high waves lasted more than five days causing widespread beach erosion and washover all along the east coast of the U.S. (Davis and Dolan, 1992). The Halloween storm began as an extratropical disturbance that was later reinforced when it merged with the remnants of Hurricane Grace. In Maine, the Halloween storm constructed thick washover deposits of cobbles (Fig. 4a), and large rocks tossed from the sea damaged some expensive seaside homes.

\section{Hurricanes (Tropical Cyclones)}

Tropical cyclones, which include tropical storms, Atlantic and Gulf hurricanes, and Pacific typhoons, are relatively small, intense storms that originate near the equator and usually travel from east to west. They form during the summer or early fall when warm seawater and 
atmospheric circulation favor storm generation (Simpson and Riehl, 1981). Hurricanes are characterized by their four most destructive forces; strong winds including tornadoes, high storm surge and washover (Fig. 5), large waves, and associated rain. The most deadly and destructive storms combine all four forces, but typically one of the forces is dominant. The Saffir-Simpson scale is used to rank hurricanes from 1 to 5 according to their strength and ability to inflict property damage. Category 4 and 5 hurricanes, such as Hurricanes Andrew and Camille, can permanently alter the coastal landscape leaving geological evidence such as erosional escarpments and washover channels that remain long after our memory of the storm has faded.

About 5 to 10 Atlantic and Gulf Coast hurricanes form each year (Riehl, 1979), but most of them do not strike land and their energy is dissipated over the open ocean rather than at the shore. Many of the Atlantic hurricanes travel parallel to or away from the coast. Also, peninsular Florida shields the eastern Gulf of Mexico from westerly moving hurricanes; nevertheless, beach erosion is a chronic problem on the west coast of Florida (Fig. 6).

The infrequent occurrence of hurricanes in some coastal areas causes periods of rapid beach erosion and widespread damage followed by calm periods when the beach is relatively stable. This sporadic land loss promotes a false sense of beach stability and safety that has led to high density development and building designs assuring that future storms will set new records in property damage and disaster relief.

In the Gulf of Mexico, a major hurricane causes dramatic land losses and substantial property damage (Fig. 4b) about every 10 years (Hayes, 1967; Nummedal et al., 1980; Morton and Paine, 1985). The greatest natural disaster in U.S. history was the 1900 hurricane that swept across Galveston Island killing nearly 8,000 people and destroying the first two blocks of homes near the ocean. Other memorable Gulf Coast storms were Hurricanes Carla (Fig. 5) and Camille. Hurricane Carla was an intense, slow moving storm that struck Texas in 1961 demolishing a row of dunes 30-50 m wide and cutting numerous washover channels across Padre Island (Hayes, 1967). In 1969 Hurricane Camille went ashore near Bay St. Louis, Mississippi causing an estimated $\$ 1.4$ billion in property damage. Strong winds and an $8 \mathrm{~m}$ storm surge collapsed a 90unit, two-story brick apartment complex and killed more than 25 people who had sought shelter from the storm. Although this expensive, well-built building was more than $200 \mathrm{~m}$ landward of the beach, across a U.S. highway, and "protected" by a seawall, the structure could not withstand the wall of water and high winds that accompanied the storm.

As population densities and coastal construction increase, each successive large storm sets records for property damage and destruction. The 1938 New England hurricane was the costliest natural disaster at its time. New York, Connecticut, Rhode Island, and Maine sustained extensive land losses (Nichols and Marston, 1939) and more than $\$ 250$ million in property damage when the September storm struck during a spring high tide. Hurricane Hugo, a recent category 4 storm, was another costly natural disaster. Although it was a fast moving storm with limited exposure time, Hugo caused economic losses of more than $\$ 7$ billion in the U.S. alone and more than 15,000 homes were destroyed (Finkl and Pilkey, 1991). Hugo's land loss and destruction were centered on the barrier islands near Charleston, South Carolina. Observations 

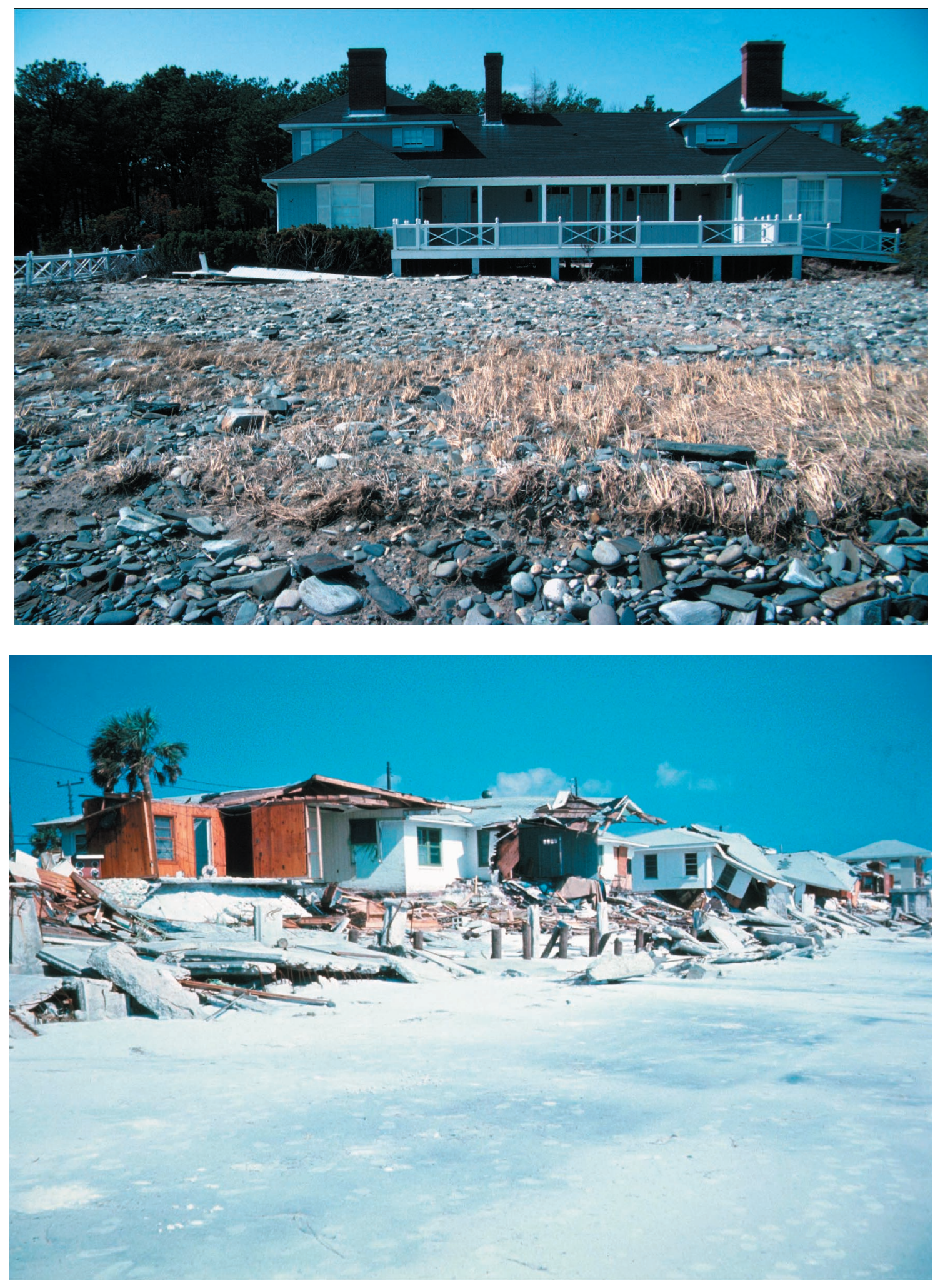

Figure 4. (A) (top) Cobble washover deposit and properties damaged by waves and wave-hurled cobbles during the 1991 Halloween storm, Wells, Maine. (B) Powerful storms such as Hurricane Eloise, erode beaches and destroy homes like these near Panama City, Florida that were built too close to the shore. From Morton (1976). 


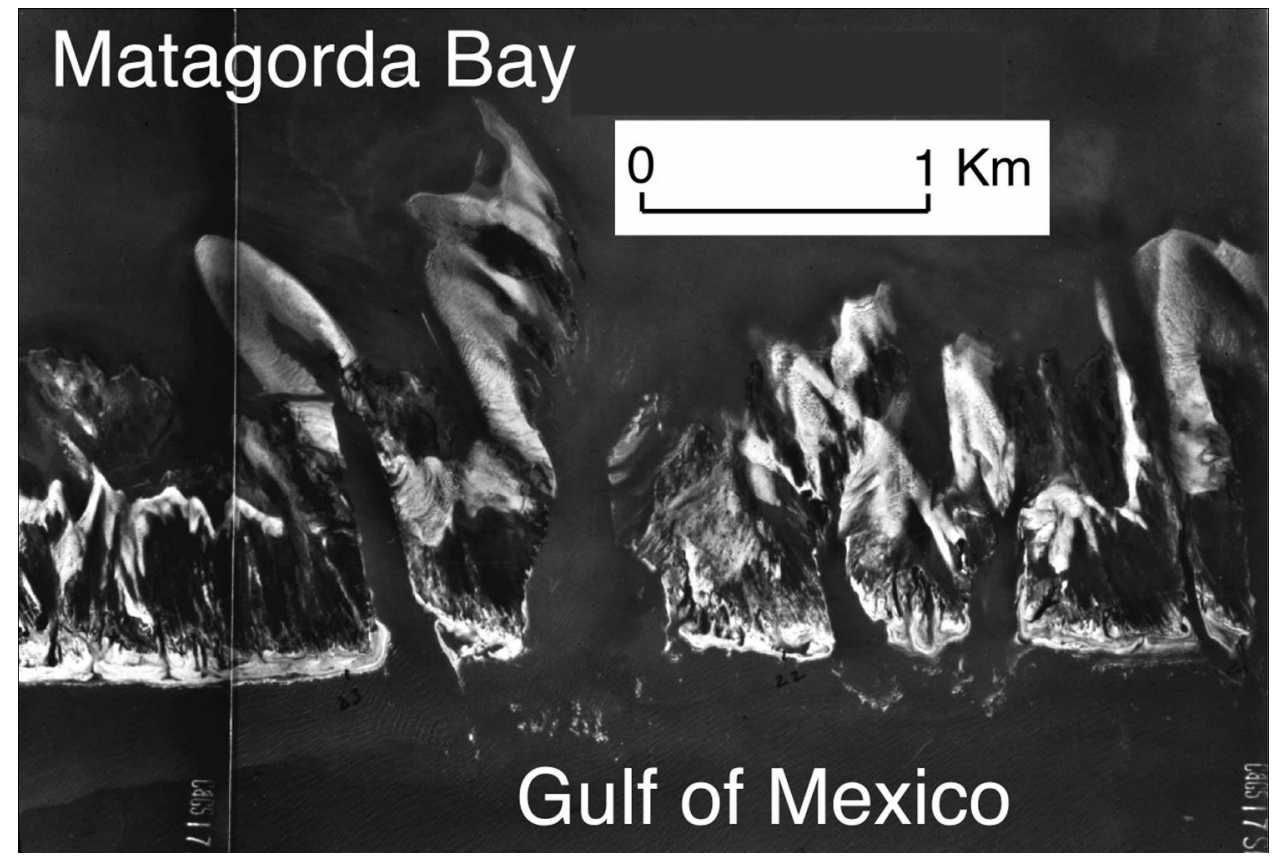

Figure 5. Hurricane Carla left its permanent mark on Matagorda Peninsula, which is a low-profile barrier island in Texas. The high storm surge, strong waves, and fast currents carved numerous washover channels through the barrier while powerful winds shaped the washover fans causing them to curve in a counterclockwise direction. Photograph provided by the National Ocean Service.

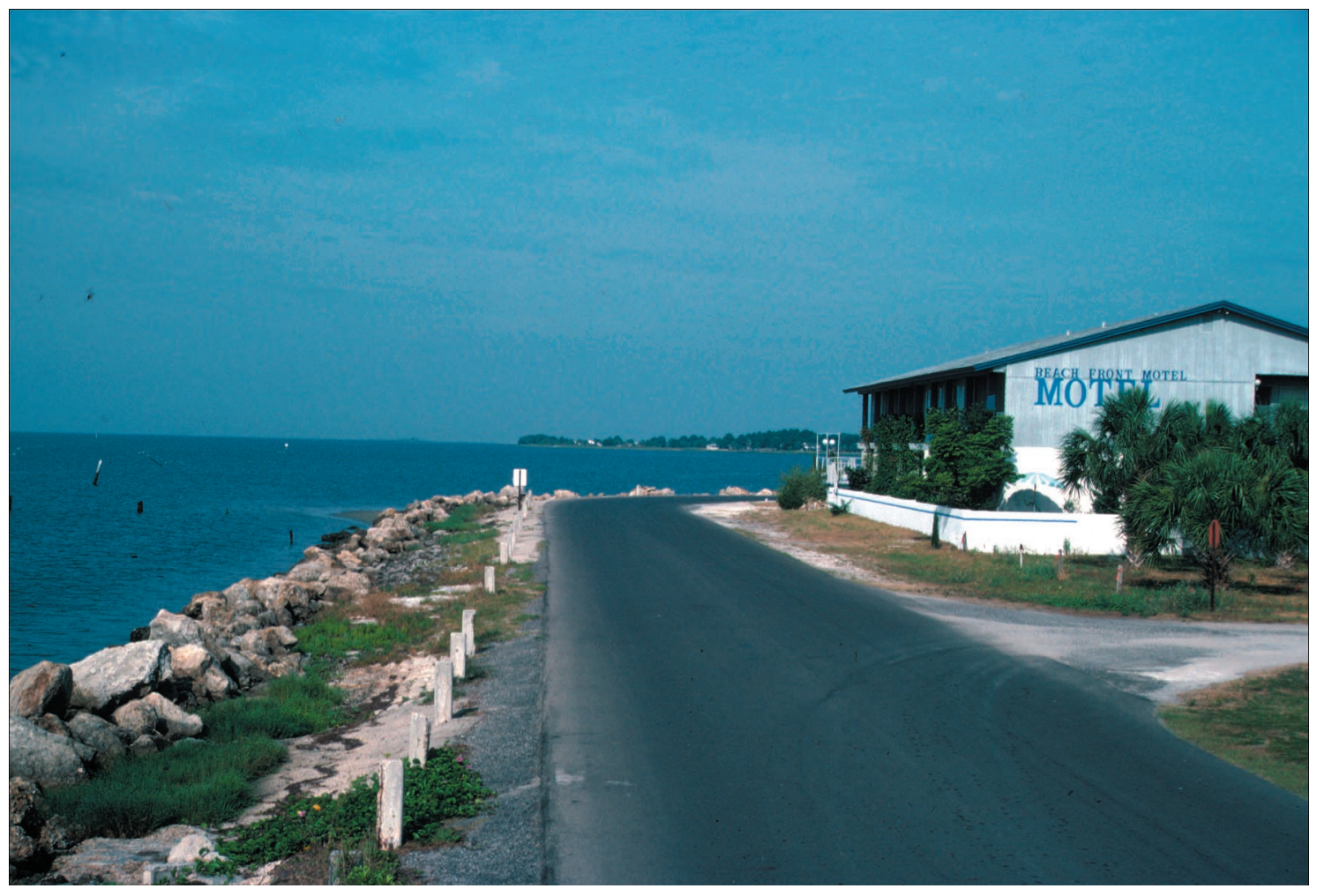

Figure 6. This beachfront motel on the low-energy west Florida coast at Cedar Key has no beach because riprap was placed on the shore to reduce long-term erosion. 
after Hugo and other storms indicate that buildings and access roads contributed to land loss by focusing currents, creating paths for washover, enhancing scour around pilings foundations, and toppling seawalls.

Hurricane Andrew in 1992 was the most destructive storm of record causing more than $\$ 15$ billion in property damage, mostly as a result of devastating winds. This storm was also unique because it crossed the coast in three places. It first came ashore near Homestead, Florida south of Miami, crossed the west coast of Florida near Naples, and then after traveling northwest it came ashore in southcentral Louisiana. Andrew caused no significant beach erosion in Florida because it was a fast moving storm that crossed the coast at a high angle and had limited fetch to generate large waves. However, Andrew's track in the Gulf of Mexico was nearly parallel to the Louisiana coast for a brief period and it caused more than $30 \mathrm{~m}$ of beach erosion and obliterated the dunes on some Louisiana barrier islands.

\section{El Niño Events}

Along the Pacific coast, winter storms and unusual oceanographic conditions such as El Niño cause the most beach erosion and land loss. Compared to other storm systems, El Niño is an infrequent, but significant event that has a profound effect on weather patterns, ocean currents, and fluctuations in sea level. About every 4 to 5 years, El Niño conditions cause warm surface water of the Pacific Ocean to flow eastward piling up water along the west coast of North and South America (Philander, 1989). The elevated water levels coupled with unusually strong storms during El Niño events cause extensive flooding and erosion of West Coast beaches (Komar and Enfield, 1987). In the spring of 1983, an unusually strong El Niño caused torrential rainfall, rapid beach erosion, and massive landslides along the Pacific coast of the United States. Land loss was concentrated along the southern California coast where numerous expensive homes built on unconsolidated bluffs were damaged or destroyed.

\section{Landslides and Cliff Retreat}

Coastal landslides occur where unstable slopes fail and land is both displaced down slope and lost (Fig. 7). Some of the fundamental causes of slope failures that lead to land loss are: (1) slope over-steepening (2) slope overloading, (3) shocks and vibrations, (4) water saturation, and (5) removal of natural vegetation. Landslides associated with bluffs are common in regions of glacial rebound (Great Lakes, New England, Puget Lowland), along active tectonic margins (Pacific Coast), or where unconsolidated uplands are exposed to high waves (Atlantic Coast, Gulf Coast).

Some land losses along sea cliffs in parts of California and Alaska are related to faulting and earthquakes, but most of the land losses along cliffs are intermittent and caused by combined marine and subaerial erosion. High storm waves attack and erode the base of the cliff, which causes over-steepening. This results in collapse of the cliff and accumulation of debris (talus) 
at the cliff base. When marine erosion is not active, surface processes (gullying and slumping) may add to the rock debris deposit that protects the base of the cliff. Eventually marine erosion removes the protective covering of rock debris, undermines the toe of the slope, and causes renewed slumping (Emery and Kuhn, 1982; Komar and Shih, 1991). Sunamura (1983) summarized the relationship between cliff erosion and cliff resistance.

Weather patterns, sea-level fluctuations, composition of the cliff, and structural dip of the cliff strata control land loss along sea cliffs. Emery and Kuhn (1982), among others, have noted that cliff retreat occurs frequently in the winter in association with storms and high rainfall. Human activities such as watering lawns and draining septic tanks can artificially increase ground-water levels and either initiate or aggravate slumping at the face of the cliff.

Cliff retreat is not necessarily catastrophic and there are many physical and chemical processes that can cause sediment to gradually accumulate in rock debris slopes. An understanding of these processes is important to avoid conducting any activity that would increase slope instability or be ineffective in controlling landslides. For example, seawalls are commonly constructed on the beach at the bases of sea cliffs to stop slumping when the processes causing the slumping are acting at the top or within the cliff. Most states with actively retreating sea cliffs have issued maps and reports that identify the hazard prone areas and describe the probability of future slope failure.

Land loss caused by slumping can also occur at scales much smaller than sea cliff retreat. For example, erosion along some tidal creeks and dredged channels is caused by bank failure that forms small slump blocks (Ginsburg and Perillo, 1990). The channels widen as the slump blocks are removed by tidal currents or by ice flowing through the channels.

\section{Sediment Budget}

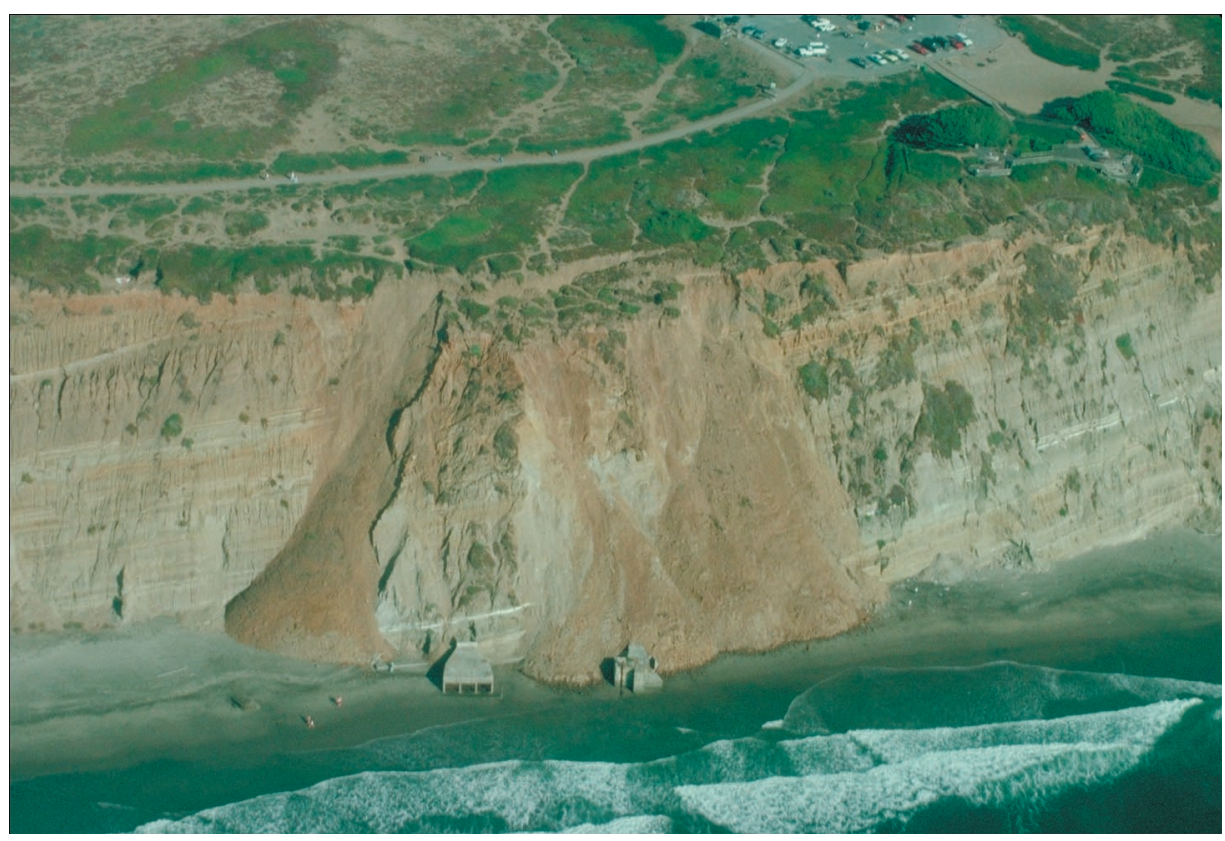

Figure 7. Elevated water levels and high waves caused by El Niño cause active landslides and rapid land loss along steep bluffs of the Pacific coast. 
Sediment budget is a concept that applies to sandy and muddy shores. It is only one of three factors (sediment budget, sea level and wave energy) that control most land loss. Sediment budget refers to the balance between sediment added to and removed from the coastal system; in this respect the coastal sediment budget is like a bank account. When more material is added than is removed, there is a surplus of sediment and the shore builds seaward. On the other hand, when more material is removed than is added, there is a deficit in sediment supply and the shore retreats landward. Coastal erosion is a physical expression of a deficit in the sediment budget where nearshore processes remove more material from the shore than is added. Stated another way, coastal recession is the result of insufficient sediment supply compared to sediment removal.

Sediment budget also refers to the sources that deliver sediment to the coast and the places where it is temporarily or permanently stored. The storage sites are known as sediment sinks. To calculate the sediment budget for a coastal segment, one must identify all the sediment sources and sinks, and estimate how much sediment is being added to or taken from the beach each year. This is an extremely difficult task and as a result, few sediment budgets have been accurately determined.

\section{Sandy Coasts}

Common sources of coastal sediment are rivers (e.g. Mississippi), eroding bluffs and dunes (e.g. Cape Cod), and the continental shelf (e.g. North Carolina Outer Banks). Sand is removed from the beach and stored in coastal dunes and storm washover deposits, as well as in tidal inlets and tidal deltas. Some sand eroded from the beach and shoreface during storms is transferred to the inner continental shelf where it is deposited in water so deep that fair-weather waves cannot return the sand to the beach. Under these conditions, the continental shelf is a permanent sand sink. Atlantic coast estuaries are large sinks for sand transported landward from the continental shelf and adjacent beaches (Meade, 1969). Along the tectonically active Pacific coast, other sediment sinks are deep submarine canyons that permanently intercept sand moving alongshore. Artificial channels and dredged inlets are also large sediment sinks that can cause imbalances in the sediment budget.

Erosion along one stretch of sandy beach may be responsible for accretion or reduced erosion of a nearby beach in a downdrift direction if the sediment volume is sufficient and the available material is compatible with downdrift beaches. On the other hand, depletion of an updrift sediment source will initiate or accelerate retreat of downdrift beaches. The type of material eroded determines whether or not nearby beaches benefit from the erosion. For example, erosion of sandy beaches provides a ready source of sand for nourishment of downdrift beaches, whereas erosion of marshes and other muddy deposits usually does not contribute to the sand budget of adjacent beaches. 


\section{Rivers and Deltas}

The amount of river sediment reaching the shore and contributing to the sediment budget varies from one coastal region to another. If the river supplies more sediment than can be redistributed by marine processes, then a delta forms such as the Mississippi Delta. Conversely if the waves and currents can remove more sediment than is being delivered to the shore, then the delta retreats or the sand load is incorporated directly into the beach and a delta is not formed. This is a common occurrence along the Pacific coast where sediment supply is relatively low but wave energy is high. In the U.S., the greatest amount of river-transported sediment is delivered to the Gulf of Mexico (Milliman and Meade, 1983). However, along the Atlantic coast south of Long Island and along most of the Gulf Coast, the sediment transported by rivers is trapped in estuaries and does not reach the ocean shore.

Land losses and land gains associated with large deltas, such as the Mississippi, are natural progressive phases in the continuous cycle of delta construction (land gain) and destruction (Wells and Coleman, 1987; Penland et al., 1988). A reduction or termination in sediment supply to one lobe of the delta caused by channel shifting results in widespread land loss as the abandoned delta lobe sinks and is inundated by marine water.

The land-gain/land-loss cycle of a Mississippi-type delta begins with breaching of the natural levee along the riverbank. This breach, known as a crevasse, forms a new channel that diverts some of the water and sediment away from the main channel and into an adjacent water body such as a lake or marine embayment. There the sediment is deposited as a new delta lobe that fills the former water body. As the crevasse deepens and widens, more sediment is delivered to the new lobe, which rapidly grows in shallow water. The channel delivery system becomes inefficient the farther the delta builds away from the main channel and eventually the crevasse begins to shoal. Finally the crevasse shoals completely at its entrance, shutting off further sediment supply to the delta. At this time, the new delta lobe enters the latter phase of the sediment budget cycle and begins to deteriorate. Deterioration is manifested as land loss caused mainly by compactional subsidence of the delta lobe, but also partly by wave erosion.

\section{Changes in Sediment Supply}

Several thousand years ago the principal suppliers of sediment to most non-cliffed coasts were either rivers that delivered sand directly to the beach or nearshore currents that transported sand onshore from the continental shelf. Once at the coastline the sand was redistributed by alongshore currents. The presence of sandy beach-ridges and barrier islands on both Atlantic and Gulf coasts indicate that sand supply was plentiful and beaches were building seaward as sea level approached its current position several thousand years ago. Since then, sediment supplied by some coastal rivers and the continental shelf has naturally diminished as a result of climatic changes and adjustments of the inner shelf profile. Humans have also contributed significantly to the deficit in sediment supply by damming rivers, building seawalls, groins, and 
jetties, and dredging tidal inlets. These natural and artificial reductions in coastal sediment supply have resulted in the erosion of many beaches, barrier islands, and deltas. Today the only remaining source of sediment for many coastal compartments is local erosion of nearby beaches and bluffs.

\section{Relative Sea Level}

There is a tendency to think of sea level as a uniform surface around the world that is used as a datum from which land elevations and ocean depths are measured. Actually sea level is not the same everywhere and it also moves up and down with time. Ocean levels in the Pacific are slightly higher than in the Atlantic and ocean levels near the equator are higher than those at the poles. The factors that spatially influence ocean levels include oceanographic conditions (currents), meteorological conditions (atmospheric pressure, wind), terrestrial conditions (river discharge), and geophysical conditions (geoid anomalies). The factors that influence temporal sea level fluctuations range from high frequency (daily, seasonal) astronomical tides to low frequency changes in global climate. Major climatic (atmospheric temperature) fluctuations over periods of thousands of years cause global sea level to fall and then rise as continental ice sheets form and subsequently melt.

The accurate term for a tide gauge record is relative sea level change because it includes the combined movement of both water and land. Even if sea level was constant there could be changes in relative sea level. For example, a rising land surface would produce a relative fall in sea level, whereas a sinking land surface would produce a relative rise in sea level.

\section{Global Sea-Level Rise and Subsidence}

Submergence refers to permanent flooding of the coast caused by a rise in global sea level and/or subsidence of the land. At many coastal sites, submergence is the most important factor responsible for land loss. How much land will be lost as a result of sea-level rise depends partly on how fast the water is rising. It has been estimated that each year global sea level rises about $1.8 \mathrm{~mm}$ as a result of a worldwide increase in water volume (Douglas, 1997). However, this value is substantially less than the total rise in relative sea level recorded at many tide gauges (Emery and Aubrey, 1991), so scientists have concluded that the remaining amount of relative sea-level rise is caused by land subsidence. At any coastal site the relative sea level includes the global sea-level component (eustasy), tectonic uplift or down warping, and at some locations subsidence that is the result of natural sediment compaction or subsidence induced by the withdrawal of subsurface fluids such as groundwater, oil, and natural gas (Morton et al., 2002). Land loss can also occur in those coastal areas that are experiencing uplift (relative fall in sea level) such as along the Pacific coast and parts of Alaska (e.g. Juneau). This is because storm surges and high waves continue to cause land loss.

Releveling surveys and tide gauge records around the world are used extensively to decipher 
crustal deformation and increased ocean volumes that occurred in response to atmospheric warming since the last period of continental glaciation. Although historical records of relative sea level are both spotty and brief in North America, the results show along-coast trends that demonstrate the interrelationships among vertical crustal motion, sediment compaction, and eustatic fluctuations (Clark et al., 1978; Peltier, 1986; Emery and Aubrey, 1991).

Several studies have demonstrated how unloading of thick continental ice sheets causes rebounding near the former glaciers and collapse of the surrounding forebulge as evacuated crustal material returns to the uplifted regions (Clark et al., 1978; Peltier, 1986). These crustalresponse models also have been used to explain the variability among historical sea-level records and current rates of vertical motion derived from those data.

Not only is sea level rising in a relative sense at many coastal sites, statistical analyses of long-term records show that the present rates of relative sea-level rise are much greater than rates of submergence were for the past few thousand years. This discrepancy between historical and geological rates of submergence has been interpreted as evidence that atmospheric warming since the industrial revolution has caused thermal expansion of the oceans (National Research Council, 1990) and melting of mountain glaciers (Gornitz and Lebedeff, 1987) and possibly the Antarctic ice sheet.

\section{Effects of Submergence}

Regardless of its cause, coastal submergence contributes to land loss in several ways. The most easily recognized effects of submergence are land losses caused by permanent flooding. The passive inundation of the shore typically expands estuaries, lakes, and lagoons at the expense of adjacent uplands and wetlands. The slope of the land surface and rate of sea level rise control the extent of permanent flooding. Steep slopes and low rates of sea-level rise produce negligible flooding, whereas low slopes and rapid rates of sea-level rise inundate such vast areas so rapidly that the submergence can be detected in a few decades. Rapid coastal submergence has been documented at Baytown, Texas (Fig. 8) near Houston and on the Mississippi Delta. Subsiding land areas experience greater and more prolonged flooding by salt water associated with storms. This means that storm surges of historical record would inundate larger areas if similar storms were to occur today. Eventually the repeated inundation by saltwater expands the flood zones and alters the predominant wetland plant assemblages. This

occurs because salinities within the wetlands and estuaries increase, as they are permanently flooded. In many coastal regions the inundation of salt water actually accelerates wetland losses because both fresh-water and salt-water marshes are destroyed faster than new wetlands are created. The intolerant fresh-water marshes are killed by salt-water, whereas the salt-water marshes are drowned and converted to open water.

Submergence also accelerates coastal erosion because it facilitates greater inland penetration of storm waves. An example is retreat of the bluffs at Calvert, Maryland on the Chesapeake Bay. As a result of submergence, some bluffs that were not previously reached by storm waves are 
subjected to erosion. In addition to accelerated land loss, coastal submergence causes intrusion of salt-water into coastal aquifers and into the rivers that empty into the estuaries. Submergence also changes surface drainage patterns, raises groundwater levels, and causes areas even above sea level to pond water and to be poorly drained. Around Pamlico Sound, North Carolina, dead trees are an indication of rising freshwater levels caused by the relative rise in sea level.

\section{CLIMATE AND LAND LOSS}

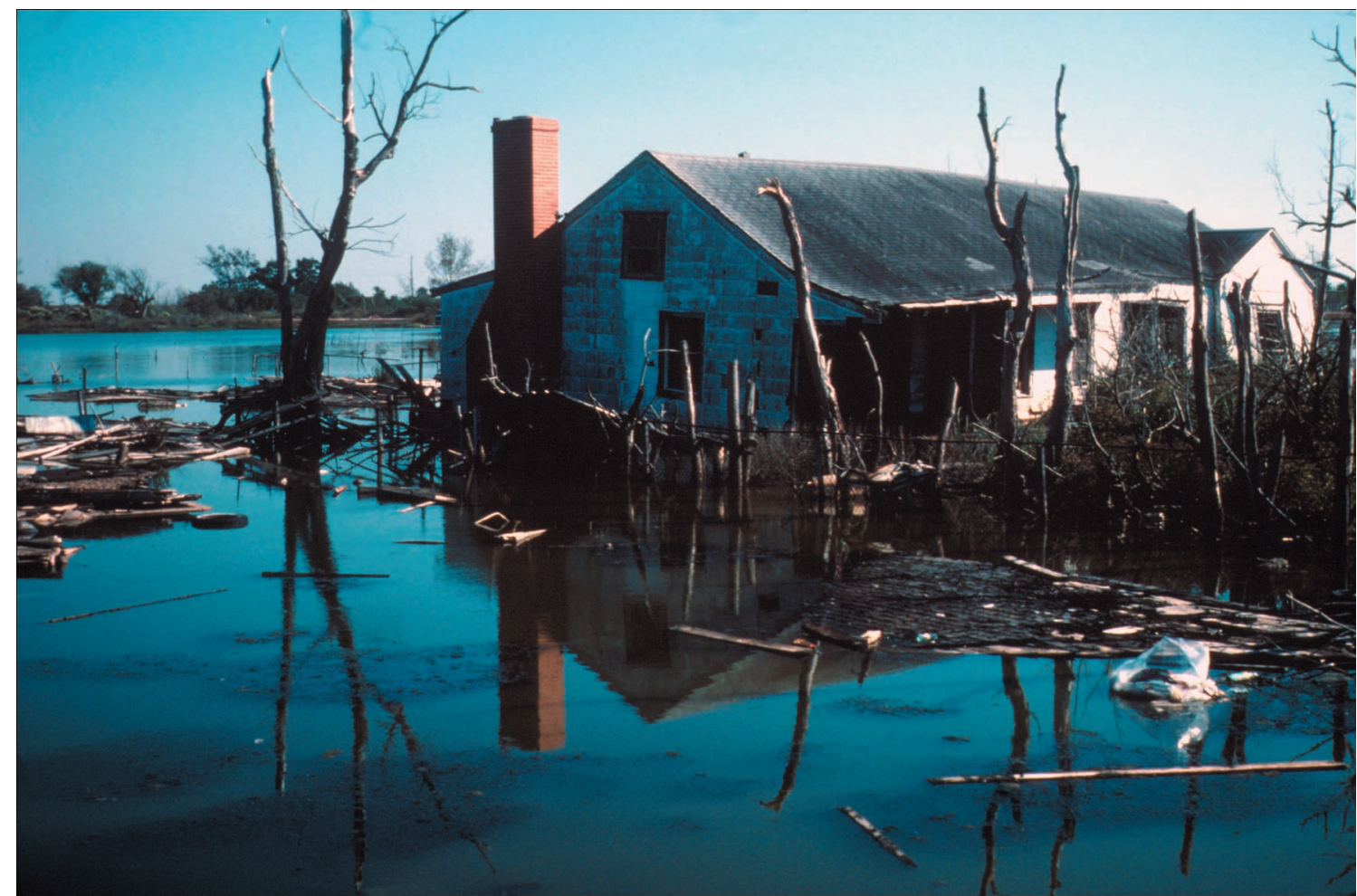

Figure 8. More than 200 homes were inundated and destroyed in the Brownwood subdivision of Baytown, Texas after the ground subsided as much as $3 \mathrm{~m}$.

Seasonal temperatures and annual precipitation indirectly influence land loss of both rocky and sedimentary shores. In New England and along the northern Pacific coast, water repeatedly frozen and thawed along fractures and bedding planes causes ice wedging of exposed sea cliffs, and prolonged thawing of permafrost promotes loss of tundra in Alaska. On the other hand, colder climate can also reduce beach retreat during the winter when sea ice forms along beaches and acts as a buffer. The beach itself can also freeze providing additional protection from wave action. Even erosion of unconsolidated bluffs is temporarily halted when the bluffs are frozen, which is a major factor controlling bluff retreat in Alaska and around the Great Lakes. Along much of the Bering Sea and Arctic Ocean coast of Alaska, the sea is covered by ice more than half of the year, reducing the annual rates of shoreline retreat.

Climate can also indirectly influence land loss by affecting the health of coastal vegetation. Vegetation weakened or killed by droughts is less resistant to wave attack than healthy vegetation, and lowered water tables during droughts expose more dry sand, which is more easily removed from beaches by wind. Furthermore, drought-related grass fires can enhance both inundation 


\section{THE ROLE OF SHORELINE CHARACTERISTICS IN LAND LOSS Composition, Induration, and Saturation}

Lithologic composition and hardness determine the land loss potential of the coast. For example, loose sand is more easily eroded than compacted, stiff mud. Hard crystalline rocks resist erosion and consequently some rocky coastlines in New England and along the Pacific coast have not changed appreciably in recorded history (Shepard and Wanless, 1971; Bird and Schwartz, 1985). Some limestones such as the coral reefs of the Florida Keys also resist erosion, but other limestones may be dissolved by underground springs that cause the land to collapse and form drowned sinkholes (Fig. 9). Some land loss along the west Florida coast near Homosassa Springs is caused by nearsurface dissolution of limestone, or karst terrane (Davis et al., 1985). These karst features are only sparsely developed and therefore no major structural damage is reported. However, these same areas would fail catastrophically like other densely developed sinkhole terranes such as near Orlando, Florida where schools and car lots have been destroyed as sinkholes collapsed.

Even height of the water table can influence the erodability of sandy beaches. The beach is less susceptible to erosion when the water level in the beach is lower than the ocean. As waves run up an unsaturated beach, the water flows into the sand. This causes deposition of sand carried by the waves and reduces the backflow of water returning to the ocean. Conversely, erosion is enhanced when the beach sand is saturated and the water level in the beach is higher

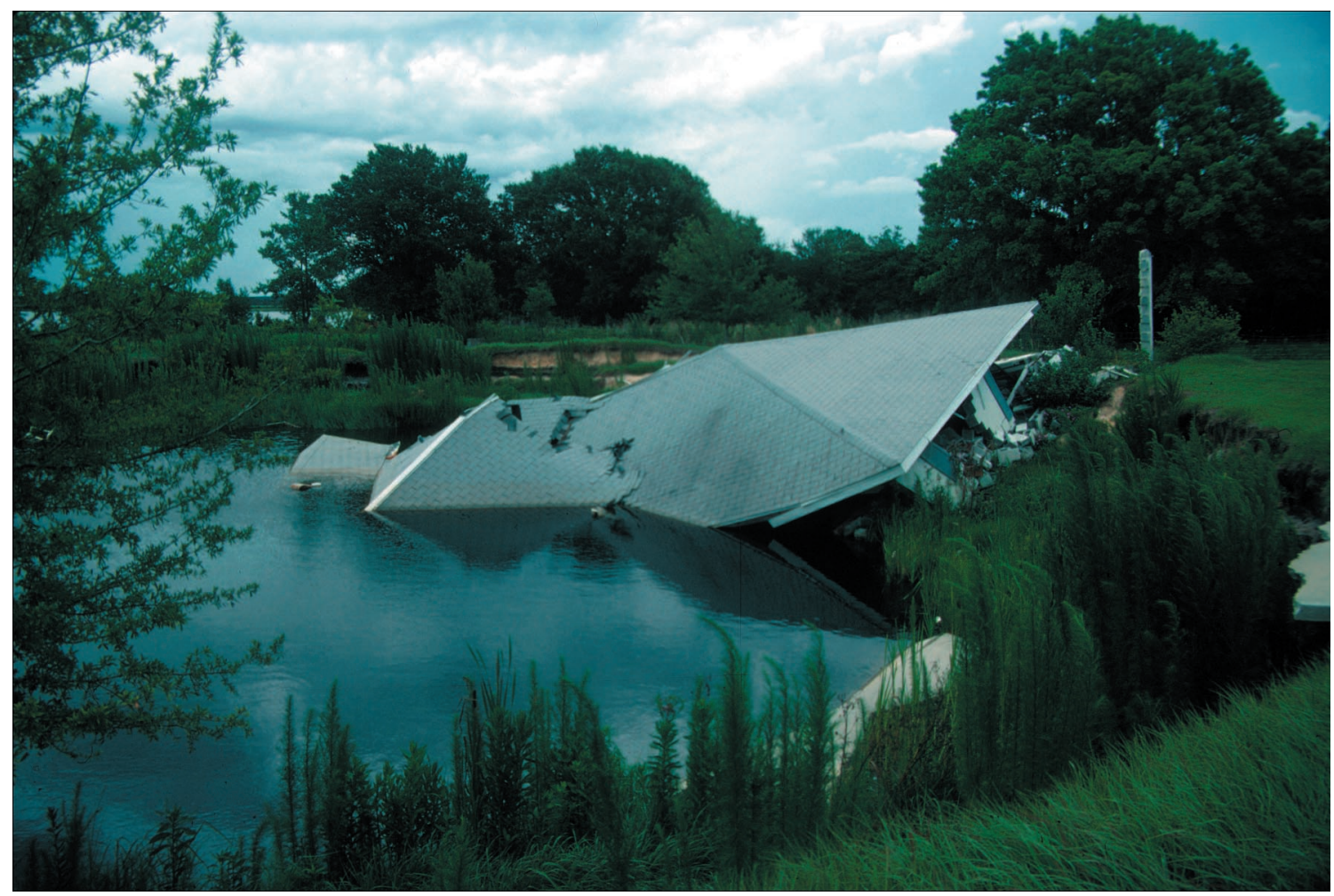

Figure 9. Collapse of sinkholes in limestone terrane causes catastrophic land loss. 
than the ocean. When this happens, water flowing out of the beach and down the beach face carries sand with it and makes the beach more susceptible to erosion.

\section{Coastal Morphology and Vegetation}

The profile and plan-view-shape of the coast also determine its vulnerability to erosion and submergence. The shore type most exposed to wave attack and erosion are tall sea cliffs. On the other hand, sea cliffs can also be the most resistant to erosion if they are composed of rock. Other things being equal, high bluffs of unconsolidated sediment should erode more slowly than low bluffs because high bluffs supply more material for the waves and currents to remove.

For the same reason, sandy beaches with large dunes should erode more slowly than those with low dunes or no dunes. Thieler and Young (1991) showed that in South Carolina, dunes more than $300 \mathrm{~m}$ wide and $5 \mathrm{~m}$ high were the only ones that were not breached by the storm waves of Hurricane Hugo. Bulkheads and revetments built in place of the dunes were all overstepped and many failed as a result of Hugo's high storm surge. These engineering structures were successful in preventing land loss or shoreline retreat, but offered little protection to the adjacent houses and buildings.

Land loss can also depend partly on smoothness of the coast and continental shelf because it affects wave energy reaching the shore. Wave energy generally increases at promontories and decreases in embayments. As a result, headlands of highly irregular coasts are attacked more vigorously by waves than long stretches of smooth sandy beaches. Wave fetch, nearshore water depths, and shoreline orientation are components of shoreline morphology that also control the wave energy reaching the coast. The greatest coastal land loss normally occurs where there are long fetches of open water, the offshore profile is steep (relatively deep water nearshore), and the waves approach the coast at a relatively high angle.

The density and type of vegetative cover also influences land loss by (1) dissipating the wave energy reaching sheltered shores, (2) encouraging the accumulation of organic and inorganic sediment, and (3) acting as a sediment binder that resists erosion. Some common coastal vegetation habitats are maritime forests, scrub thickets, grassy upland prairies, fresh-water swamps, fresh-water marshes, mangrove swamps, salt-water marshes, and grassy or forested dunes.

Each type of coastal vegetation has its own unique features that can retard land loss. For example, dense stands of salt marsh and mangroves trap sediment or offer resistance to waves and currents so that land loss is prevented or mitigated. Dune grasses also help stabilize blowing sand and can assist in dune enlargement. However, the roots of grasses and trees are generally too shallow to reduce erosion from large storm waves that lower the backbeach and undercut the dunes or uplands.

\section{THE ROLE OF HUMAN ACTIVITIES IN LAND LOSS}


There is increasing evidence that recent accelerated land losses in many coastal regions are largely anthropogenic and attributable to human alteration of the littoral system and wetland environment. Land losses indirectly related to human activities are difficult to quantify because they promote alterations and imbalances in the primary factors causing land loss such as sediment budget, coastal processes, and relative sea level (Fig. 2). Coastal construction, land excavation, and extraction of hydrocarbons and groundwater now account for the greatest losses of wetlands and barrier islands where these natural resources have undergone intensive economic development for more than 50 years.

Human activities causing land loss are discussed according to their impacts on the physical agents (Fig. 1). The linkage between human activities and the physical agents is as follows: transportation networks tend to increase erosion, coastal construction projects typically increase deficits in the sediment budget, subsurface fluid extraction and climate alterations accelerate submergence, and excavation causes direct losses of land.

\section{Transportation}

Shipping has always played a vital role in our nation's economy and it was for that reason that shallow coastal waters were deepened in the 1800 s to create or enlarge major ports and harbors that were busy centers of commerce. Abnormally high rates of land loss occur along ship channels and service canals as well as along natural tidal channels that are frequently used as transportation routes. Bow waves of large ships and wakes of smaller vessels alternately raise and lower water levels generating local waves and currents that erode the banks and enlarge the navigation channels. Periodic dredging of the Intracoastal Waterway that stretches from Maine

to Texas is necessary because the channel shoals from the material eroded from the banks by bow waves. Even commercial and recreational boating in tidal creeks of coastal marshes can cause bank erosion and enlargement of channels such as those crossing the marshes of the Mississippi Delta and the Eastern Shore of Virginia.

Rates of land loss caused by these artificial processes are typically controlled by the amount of boat traffic, channel age, channel-bank composition, and channel setting. Land loss rates are greatest where boat traffic is high, channels are relatively new, and channel banks are steep and composed of sandy sediments. Land loss rates are also unusually high where channels are narrow and restricted by high banks that cause wave and current energy to be dissipated against the channel banks. As an example, maintenance dredging of a federal anchorage in Wells, Maine has been halted by the State in part because of the wetlands losses associated with the artificially deepened channel.

\section{Coastal Construction}

Engineering structures such as groins, breakwaters, seawalls/bulkheads, and revetments are designed to control coastal land loss, but they can accelerate land loss of adjacent beaches 
(Fig. 10, Morton, 1988b) by changing wave refraction patterns and depleting sand supply. Shore-parallel structures cause erosion by narrowing the beach as the shoreline retreats. Some shore-normal structures contribute to erosion by either trapping sand that would normally move alongshore or directing the sediment-laden currents offshore causing permanent losses of beach sand.

Seawalls and bulkheads can contribute to incomplete storm beach recovery by limiting the onshore transportation and deposition of sand. The structures can decrease the effective width of dry beach needed for eolian transport and prevent the progressive transfer of sand from the forebeach to the backbeach. As a result of this interference with the sand budget, natural dune restoration is prevented or prolonged and the total beach recovery is either incomplete or delayed.

\section{River Modification}

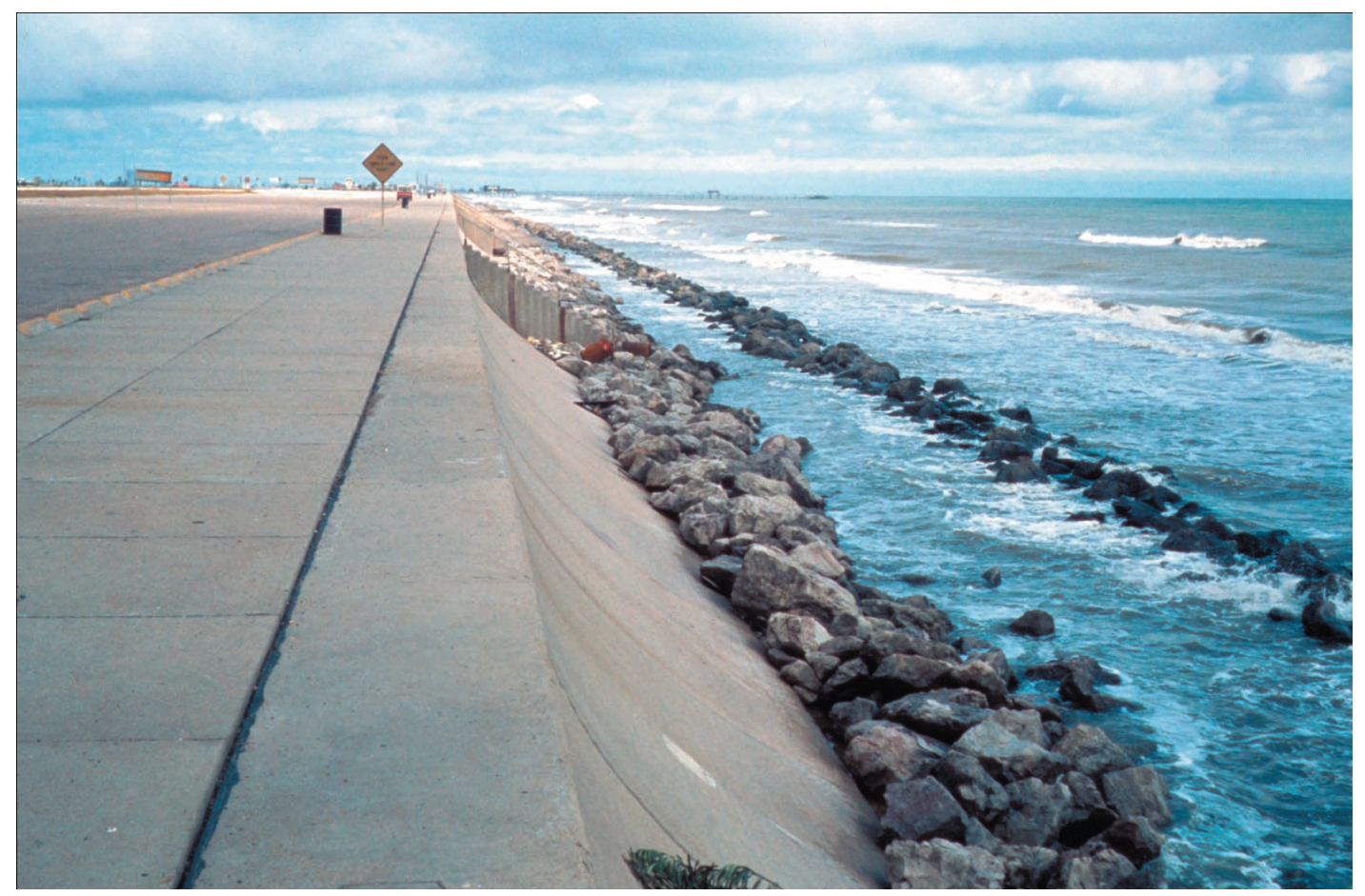

Figure 10. Hard structures, such as the Galveston seawall, can increase erosion of adjacent beaches.

In the western Gulf of Mexico, along the Pacific coast, and in parts of New England, artificial inland lakes and other freshwater impoundments also contribute to coastal land loss by regulating river discharge and sediment load delivered to downstream deltas and beaches. Dams used to store potable water supplies, control floods, and provide recreation have a doubly negative effect on land loss by trapping sediment and eliminating peak flood discharges. It is these highest discharges that are responsible for flushing the lower reaches of rivers and transporting most of the sediment to the coast. Proposed plans to build sediment-bypass structures at dams ignore the fact that this will only stockpile sediment below the dams and will be inefficient without unregulated floods to transport the material farther downstream. 
The most extensive control of a river system in the United States is confinement of the Mississippi River and prevention of it switching into the Atchafalya River channel. Construction of high levees along the main channel and distributaries of the Mississippi River, which began in the early 1700s (Davis, 1990), has dramatically reduced the frequency and volume of sediment deposited on the levees and adjacent delta plains. Consequently, land loss on the delta plains has accelerated at an alarming rate and costly projects are currently being conducted to mitigate the wetland losses or to construct new wetland areas.

\section{Hydrocarbon and Groundwater Extraction}

Land subsidence can be induced by any one of several different activities that involve large volume extraction of underground resources (water, oil and gas, sulfur, salt). Land loss associated with induced subsidence is actually more common than most people realize, especially where large volumes of fluids are removed from underground formations. This induced subsidence, which is either sub-regional or local in extent, has its greatest impact on flat coastal plains and wetlands near sea level where minor lowering of the land surface results in permanent inundation. For more information about induced subsidence, see the Subsidence and Fault Activation Related to Fluid Energy Production, Gulf Coast Basin Project on the Internet at http://coastal.er.usgs.gov/gc-subsidence/.

Subsidence around the Goose Creek Oil field near Houston, Texas was the first evidence that rapid, large volume extraction of hydrocarbons was capable of causing the ground to sink around the producing wells. The induced subsidence, which was discovered shortly after field development began in 1917, indicated that accelerated withdrawal of oil, gas, and associated water from shallow unconsolidated reservoirs could lower the land elevation, cause minor earthquakes, and activate faults around the periphery of producing fields (Pratt and Johnson, 1926).

One of the most dramatic cases of land subsidence caused by oil and gas production occurred at the Wilmington Field in Long Beach, California. As the oil reservoirs were depleted, sand compaction caused almost $9 \mathrm{~m}$ of land subsidence that flooded streets and wharfs and caused structural damage to bridges, railroads, and other harbor facilities (Poland and Davis, 1969). However, the subsidence did not cause widespread land loss because the subsidence bowl only covered about $35 \mathrm{~km}^{2}$.

Induced subsidence in the Houston-Galveston area, which covers more than $12,000 \mathrm{~km}^{2}$, has lowered the land surface as much as $3 \mathrm{~m}$. This subsidence bowl is largely a result of long-term industrial ground-water withdrawal from shallow aquifers (Gabrysch, 1984) and deeper oil and gas extraction (White et al., 1985). Near the center of the subsidence bowl, more than 200 homes in a middle class neighborhood of Baytown, Texas were destroyed after groundwater extracted for the petrochemical industry caused the area to subside, flooding the entire subdivision (Fig. 8). Subsidence induced by fluid withdrawal is usually an irreversible process because it usually 
involves sediment compaction and dewatering of interbedded clays.

In the Gulf Coast region, subsidence induced around large, mature oil and gas fields is also locally concentrated along linear trends that coincide with faults (White and Morton, 1997). Extraction of hydrocarbons and formation water causes a decline in pore pressure within the reservoirs and alters the state of stress near the faults. Because of the slope of the fault plane and its intersection with the land surface, fault-plane subsidence may be surficially expressed more than $2 \mathrm{~km}$ away from the producing wells.

Relatively little is known about the severity of land loss caused by induced subsidence and the relationship of land loss to production history, fluid composition, local geology, and near-surface conditions prior to hydrocarbon or groundwater production. Except along the northern Gulf of Mexico and in southern California, land losses associated with subsurface fluid withdrawal are minor. But continued withdrawal and concomitant decline in fluid pressure from hydrocarbon extraction and ground-water pumping could eventually cause even greater lowering of land elevations. This would augment the effects of relative sea-level rise and lead to additional land losses near the coast.

\section{Climate Alteration}

There is growing concern that global warming of the atmosphere from burning fossil fuels will cause continued thermal expansion of the oceans and possibly melting or disintegration of the West Antarctic ice sheet (Barth and Titus, 1984; National Research Council, 1990). The increased volume of water liberated by these processes would accelerate the global rise in sea level and cause flooding of low-lying coastal regions. Current scientific debate about future sea level conditions focuses on identifying the local components of relative sea level and how each of those components will be altered if future global warming is consistent with recent predictions.

Although the causal correlation of a global rise in sea level with global warming appears reasonable, predictions of greater storm frequency and intensity as a result of altered global climate are still speculations because long-term atmospheric and climatic models are imprecise. Even meteorologists disagree as to the likelihood of exceptionally intense storms either in the future or in the past when geological evidence indicates global temperatures were warmer. Counterbalancing forces attempt to maintain fluid equilibrium by preventing development of extreme atmospheric conditions. Increased carbon dioxide in the atmosphere would increase global temperatures, but these conditions can also cause offsetting reactions such as increased cloudiness that would limit warming of the earth.

Significantly increased global temperatures would shift the zone where tropical cyclones form into higher latitudes and extend the season of ice-free ocean, thus providing greater opportunity for storm influence and possibly greater land loss. But higher temperatures would also decrease thermal gradients between the poles and equator and possibly reduce the sharp temperature contrasts that are so critical to intensification of extratropical storms. Human impact on global climate has already been demonstrated; what remains unknown is how much the climate will be 
modified during the next century (Barth and Titus, 1984; Titus, 1988).

\section{Coastal Excavation}

Excavation is associated with economic development of coastal lands that involves dredging and mining of wetlands and uplands. Excavation causes the most rapid and direct conversion of land to open water. This direct removal technique is used to dredge marinas, open pipeline trenches, create or enlarge navigation channels and mosquito control ditches, construct waterfront developments with finger canals, and construct channels to provide access to drilling rig

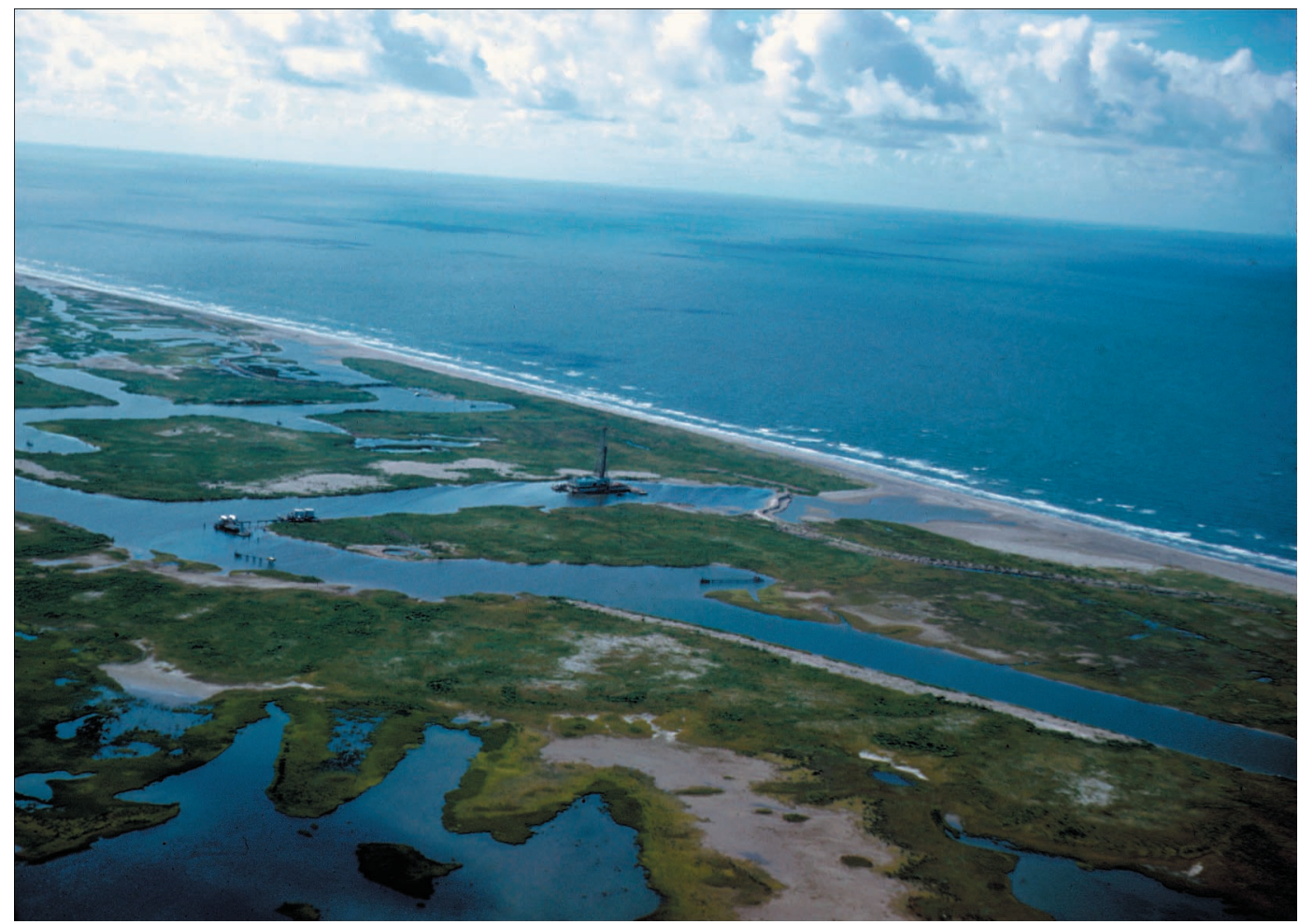

Figure 11. Dredged canals have destroyed vast wetlands in Louisiana and other coastal areas.

locations (Fig. 11).

Deep-draft navigation channels are often constructed from artificial inlets or converted from tidal inlets and rivers. Regardless of their origin they always create large sediment sinks that remove some beach-quality sand from the littoral system. Newly created channels intercept currents and redirect flow altering the hydrodynamics of coastal water bodies and sediment dispersal patterns. In turn these modifications can initiate or accelerate land loss by locally enhancing erosive forces, increasing water levels, and decreasing sediment supply. Long jetties protecting the channels can compartmentalize the coast disrupting the flow of littoral drift and preventing the exchange of sand between adjacent coastal compartments. Historically the sediment dredged from navigation channels has been placed in spoil disposal sites located either on land or in relatively deep water on the continental shelf. The dredged material normally contains at least some beach-quality sand or it may be entirely suitable for beach replenishment. Along the California coast, sand dredged from some harbors is returned to the beach, otherwise 
removal of beach sand from the littoral system by navigation projects constitutes a net loss to the sediment budget. Morton (1979) estimated that since their construction, impermeable jetties of the Texas coast trapped more than $50 \%$ of the sand liberated by updrift erosion. Clark (1991) also reported that sand losses at inlets were largely responsible for beach erosion in Florida.

Some minor land losses are directly associated with mining and other resource extraction activities. Resource extraction includes mining beaches and barriers for heavy minerals and construction aggregate (sand and gravel), mining peat for horticultural uses, and dredging reefs and bay-margin deposits for shell that is used as road material or to manufacture cement.

These extraction activities may also indirectly cause additional land losses by changing water circulation patterns, decreasing sediment supply, and increasing water depths. For example, mining large volumes of shell from bays and estuaries removes natural breakwaters, such as reefs and marine grass flats, and increases wave energy along some shoreline segments. Even mining sand on the inner continental shelf for beach restoration can cause additional land losses by altering wave refraction patterns and concentrating wave energy on the beach as a result of the depression created. Beach erosion has accelerated at several sites as a result of beach replenishment projects that dredged sand from the nearby continental shelf.

At Grand Isle, Louisiana, beach erosion increased and the shore became highly irregular after a borrow pit was dug about $1 \mathrm{~km}$ offshore to replenish the beach (Combe and Soileau, 1987). A large hole 3 to $6 \mathrm{~m}$ deep was left on the floor of the Gulf of Mexico after more than 5,000,000 cubic meters of sediment were dredged for the beach fill. The hole altered the paths of incoming waves and locally focused some of the wave energy causing the accelerated erosion.

\section{WETLAND LOSSES}

Wetland losses involve conversion of wetlands to open water either by expansion of existing water bodies (channels, lakes, ponds) or creation of new water bodies. This strict definition does not include burial of wetlands by spoil material or draining wetlands for agricultural or urban uses because these activities do not cause land loss, but rather a gain in land area.

There are opposing opinions as to whether natural causes or human activities are responsible for most of the wetland losses in the U.S. This is because there have been few studies that measured wetland losses and also determined the actual causes. In New England, marshes are small enough that the causes of wetlands deterioration and destruction can often be isolated and identified, but in vast wetland areas such as the Louisiana delta plain and the Florida Everglades where losses are caused by many factors, a comparison of natural land losses to anthropogenic losses has not been made.

Louisiana wetlands are unique in their extent and they coincide with valuable fuel and mineral resources. They form the surface of very thick and young sediments that are weak and compressible because of their deltaic origin. Today organic production in the Louisiana wetlands is incapable of keeping up with submergence because the influx of inorganic sediments has been eliminated primarily by human activities. On a geological time scale, sediment deposited by the 
Mississippi River compensated for the relative rise in sea level and new land was constructed because of abundant sediment supply. After each delta lobe was abandoned, natural land losses were initially high, especially those losses caused by submergence and shoreline erosion. Subsequent land losses gradually declined as each delta lobe grew older (Craig et al., 1979; DeLaune et al., 1983).

Correlation of land loss rates in south Louisiana with the regional geologic framework and delta age is clear evidence that natural processes are a predominant cause of wetland loss on the delta plain. The interconnected network of dredged canals in the Louisiana wetlands (Fig. 11) account for about $10 \%$ of the land losses, but they may be responsible indirectly for additional losses of vegetation caused by intrusion of saltwater into freshwater marshes, changes in marsh hydrology, changes in sediment dispersion, and changes in nutrient distribution (Scaife et al., 1983).

Most interior wetland losses along the Gulf Coast are caused indirectly by stream control that reduces the magnitudes and frequencies of flooding. These alterations to the coastal hydrologic system have two adverse effects on wetlands productivity and viability. First, the reduced flooding prevents deposition of overbank sediments that are vital to land-surface aggradation and wetlands maintenance. Second, the reduced freshwater inflow allows saltwater encroachment, which kills the fresh and brackish water marshes and swamps.

Many marshes in New England and the southeastern coastal states are building upward as fast as the land is subsiding so these marshes are being maintained. However in the Gulf Coast, most interior marshes away from the streams are not receiving sufficient sediment to prevent their submergence and deterioration. Deposition of sediment across the marshes is seasonal; deposition is greatest in the winter when strong winds immediately preceding passage of cold fronts transport suspended sediments into the marsh (Reed, 1989). Except for infrequent episodic deposition associated with hurricanes, marsh deposition rates are lowest in the summer and also in the spring. In Louisiana, low rates of sediment deposition are a result of flood control structures and levees on the Mississippi River and its distributaries. Before river control, spring floods annually delivered large volumes of suspended sediment across the delta plain helping maintain marsh elevations even on inactive delta lobes.

The powerful forces that devastate developed coasts can actually be beneficial to maintenance of some disintegrating wetlands and the creation of new wetlands (Conner et al., 1989). Storms import new sediment for wetland construction and circulate nutrient-rich water that stimulates new plant growth. These same storm currents redistribute seeds and can establish new stands of marsh or mangroves while the reflux of storm waters exports organic detritus out of the marsh.

Compared to rocky shores and sandy beaches, wetlands are much more susceptible to deterioration and destruction. In addition to losses associated with storms and subsidence, wetlands also can be destroyed by physical contact, such as infestations of herbivores, bacterial infections, freezes, fires, and pollution (Fig. 1). Marshes are particularly vulnerable to repeated or heavy traffic of marsh buggies and tracked vehicles that depress the ground surface and 
kill the vegetation. Large populations of muskrats and nutria, an imported rodent accidentally introduced in Louisiana in the 1920s, have destroyed some marshes. Prolonged or unusually cold temperatures or accidental burning caused by lightning can also kill wetlands vegetation. Numerous wetland areas have declined or have been destroyed as a result of oil spills caused by pipeline breaks or tanker accidents. The discharge of saltwater and drilling fluids associated with petroleum exploitation has been responsible for the decline or death of some marshes.

Other wetland losses are associated with old land reclamation projects that failed. In Louisiana, land reclamation began in the early 18th century and reached its zenith in the early 1900s. However, these efforts eventually resulted in land loss as levees sank, organic soils decomposed, and the wetlands subsided (Craig et al., 1979). Land reclamation in the Florida Everglades has also had disastrous consequences causing as much as $2 \mathrm{~m}$ of land subsidence (Holzer, 1984). Draining of marshes and swamps typically causes subsidence because water saturated peats and organic-rich soils initially lose as much as $75 \%$ of their volume when they are exposed to the air and allowed to dry (Snowden et al, 1977).

\section{ACKNOWLEDGMENTS}

This work was completed as part of the US Geological Survey National Assessment of Coastal Change Project. Some of the text and diagrams were initially prepared as part of a short course on coastal land loss presented in collaboration with Orrin Pilkey (Duke University) and Joe Kelley (University of Maine). Betsy Boynton prepared the illustrations and Jolene Shirley designed the webpage layout. Ginger Garrison and John Lisle conducted critical reviews that improved the accuracy and clarity of the report.

\section{REFERENCES}

Barth, M. C., and Titus, J. G., 1984, Greenhouse effect and sea level rise: Van Nostrand Reinhold Company, New York, $325 \mathrm{p}$.

Bird, E. C. F., and Schwartz, M. L., 1985, The World's Coastline: Van Nostrand Reinhold Co., New York, p.

Clark, J. A., Farrell, W. E., and Peltier, W. R., 1978, Global changes in post-glacial sea level: a numerical calculation: Quaternary Research, v. 9, p. 265-287.

Clark, R., 1991, Beach conditions in Florida: Florida Department of Natural Resources, Division of Beaches and Shores, Technical Memorandum 89-1, 200 p.

Combe, A. J., and Soileau, C. W., 1987, Behavior of man-made beach and dune, Grand Isle, Louisiana: Coastal Sediments '87, American Society of Civil Engineers, v. 2, p. 1232-1242.

Conner, W. H., Day, J. W., Jr., Baumann, R. H., and Randall, J. M., 1989, Influence of hurricanes on coastal ecosystems along the northern Gulf of Mexico: Wetlands Ecology and Management, v. 1, p. 45-56.

Craig, N. J., Turner, R. E., and Day, J. W., Jr., 1979, Land loss in coastal Louisiana: Environmental Management, v. 3, p. 133-144. 
Dahl, T.E., 2000, Status and trends of wetlands in the conterminous United States 1986 to 1997: U.S. Department of the Interior Fish and Wildlife Service, $82 \mathrm{p}$.

Davis, D. W., 1990, Living on the edge: Louisiana's marsh, estuary, and barrier island population:

Transactions Gulf Coast Association of Geological Societies, v. 40, p.147-159.

Davis, R. A., Hine, A. C., and Belknap, D. F., eds., 1985, Geology of the barrier island and marshdominated coast, west-central Florida: Geological Society of America, Annual Meeting Field Trip Guidebook, $119 \mathrm{p}$.

Davis, R. E., and Dolan, R., 1992, The "All Hallow's Eve" coastal storm - October, 1991: Journal of Coastal Research, v.8, p. 978-982.

DeLaune, R. D., Baumann, R. H., and Gosselink, J. G., 1983, Relationships among vertical accretion, coastal submergence, and erosion in a Louisiana Gulf Coast marsh: Journal of Sedimentary Petrology, v. 53, p. 147-157.

Douglas, B. C., 1997. Global sea rise; a redetermination. Surveys in Geophysics, 18: 279-292.

Emery, K. O., and Kuhn, G. G., 1982, Sea cliffs: Their processes, profiles, and classification: Geological Society of America Bulletin, v.93, p. 644-654.

Emery, K. O., and Aubrey, D. G.,1991, Sea levels, land levels, and tide gauges: Springer-Verlag, New York, $237 \mathrm{p}$.

Finkl, C. W., and Pilkey, O.H., eds., 1991, Impacts of Hurricane Hugo: September 10-22, 1989: Journal of Coastal Research Special Issue 8, 356 p.

Gabrysch, R. K., 1984, Ground-water withdrawals and land-surface subsidence in the HoustonGalveston region, Texas: Texas Department of Water Resources Report 287, 64p.

Ginsburg, S. S., and Perillo, G. M. E., 1990, Channel bank recession in the Bahia Blanco Estuary, Argentina: Journal of Coastal Research, v.6, p. 999-1009.

Gornitz, V., and Lebedeff, S., 1987, Global sea level changes during the last century, in Nummedal, D., Pilkey, O. H., and Howard, J. D., eds., Sea-level fluctuation and coastal evolution: Society of Economic Paleontologists and Mineralogists Special Publication 41, p. 3-16.

Hayes, M. O., 1967, Hurricanes as geological agents; Case studies of Hurricane Carla, 1961 and Cindy, 1963: The University of Texas at Austin, Bureau of Economic Geology Report of Investigations 61, $54 \mathrm{p}$.

Holzer, T. L., ed., 1984, Man-induced land subsidence: Geological Society of America, Reviews in Engineering Geology, v. 6, 221p.

Komar, P. D., and Enfield, D. B., 1987, Short-term sea-level changes and coastal erosion, in Nummedal, D., Pilkey, O. H., and Howard, J. D., eds., Sea-level fluctuation and coastal evolution: Society of Economic Paleontologists and Mineralogists Special Publication 41, p. 17-27.

Komar, P. D., and Shih S.-M., 1991, Sea-cliff erosion along the Oregon Coast: American Society of Civil Engineers, Coastal Sediments '91, v. 2, p. 1558-1570.

Meade, R. H., 1969, Landward transport of bottom sediments in estuaries of the Atlantic coastal plain: Journal of Sedimentary Petrology, v. 39, p. 222-234. 
Milliman, J. D., and Meade, R. H., 1983, World-wide delivery of river sediment to the oceans: Journal of Geology, v. 91, p. 1-21.

Morton, R. A., 1976, Effects of Hurricane Eloise on beach and coastal structures, Florida Panhandle: Geology, v. 4, p. 277-280.

Morton, R. A., 1977, Historical shoreline changes and their causes: Transactions Gulf Coast Association of Geological Societies, v. 27, p. 352-364.

Morton, R. A., 1979, Temporal and spatial variations in shoreline changes, Texas Gulf Coast: Journal of Sedimentary Petrology, v. 49, p. 1101-1111.

Morton, R. A., 1988a, Great storms, in Clifton, H. E., ed., Sedimentological consequences of convulsive geologic events: Geological Society of America, Special Paper 229, p. 7-22.

Morton, R. A., 1988b, Interactions of storms, seawalls and beaches of the Texas coast: Journal of Coastal Research, v. 4, p. 113-134.

Morton, R., Guy, K., Hill, H., and Pascoe, T., 2003, Regional morphological responses to the 1962 Ash Wednesday storm : Proceedings Coastal Sediments '03,

Morton, R. A., and Paine, J. G., 1985, Beach and vegetation-line changes at Galveston Island, Texas; Erosion, deposition, and recovery from Hurricane Alicia: The University of Texas at Austin, Bureau of Economic Geology Geological Circular 85-5, 39 p.

Morton, R. A., Buster, N. A., and Krohn, M. D., 2002, Subsurface controls on historical subsidence rates and associated wetland loss in southcentral Louisiana: Transactions Gulf Coast Association of Geological Societies, v. 52, p. 767-778.

Morton, R. A., Guy, K. K., Hill, H. W., and Pascoe, T., 2003, Regional morphological responses to the March 1962 Ash Wednesday storm: Proceedings Coastal Sediments '03, 11p.

National Research Council, 1990, Sea level change: National Academy Press, Washington, D.C., 234 p.

Nichols, R.L. and Marston, A.F., 1939. Shoreline changes in Rhode Island produced by Hurricane of September 21, 1938: Bulletin Geological Society of America, v. 50, p. 1357-1370.

Nummedal, D., Penland, S., Gerdes, R., Schram, W., Kahn, J., and Roberts, H., 1980, Geologic response to hurricane impact on low-profile Gulf Coast barriers: Transactions Gulf Coast Association of Geological Societies, v. 30, p. 183-195.

O'Brien, M.P., and Johnson, J. W., 1963, The March 1962 storm on the Atlantic coast of the United States: Proceedings 8th Coastal Engineering Conference, p. 555-562.

Peltier, W. R., 1986, Deglaciation-induced vertical motion of the North American continent: Journal of Geophysical Research, v. 91, p. 9099-9123.

Penland, S., Boyd, R., and Suter, J. R., 1988, Transgressive depositional systems of the Mississippi delta plain: a model for barrier shoreline and shelf sand development: Journal of Sedimentary Petrology, v. 58, p. 932-949.

Philander, George, 1989, El Niño and La Nina: American Scientist, v. 77, p. 451-459.

Pilkey, O. H., Morton, R. A., Kelley, J. T., and Penland, S., 1989, Coastal land loss: American Geophysical Union, Short Course in Geology, v. 2, 73 p.

Poland, J. F. and Davis, G. H., 1969, Land subsidence due to withdrawal of fluids, in Varnes, D. 
J., and Kiersch, eds., Review in Engineering Geology, v. II: Geological Society of America, p. 187-303.

Pratt W. E., and Johnson, D. W., 1926, Local subsidence of the Goose Creek Oil Field: Journal of Geology, v. 34, p. 577-590.

Reed, D. J., 1989, Patterns of sediment deposition in subsiding coastal salt marshes: The role of winter storms: Estuaries, v. 12, p. 222-227.

Riehl, H., 1979, Climate and weather in the tropics: Academic Press, New York, 611 p.

Roberts, H. H., Huh, O. K., Hsu, S. A., Rouse, L. J., and Rickman, D., 1987, Impact of cold-front passages on geomorphic evolution and sediment dynamics of the complex Louisiana coast: American Society of Civil Engineers, Coastal Sediments '87, p.1950-1963.

Scaife, W. W., Turner, R. E., and Costanza, R., 1983, Coastal Louisiana recent land loss and canal impacts: Environmental Management, v. 7, p. 433-442.

Shepard, F. P., and Wanless, H. R., 1971, Our Changing Coastlines: McGraw Hill, New York, p. Simpson, R. H., and Riehl, H., 1981, The hurricane and its impact: Louisiana State University Press, Baton Rouge, $398 \mathrm{p}$.

Snowden, J. O., Simmons, W. B., Traughber, E. B., and Stephens, R. W., 1977, Differential subsidence of marshland peat as a geologic hazard in the greater New Orleans area, Louisiana: Transactions Gulf Coast Association of Geological Societies, v. 27, p. 169-179.

Sunamura, T., 1983, Processes of sea cliff and platform erosion, in Komar, P.D., Handbook of coastal processes and erosion: CRC Press, Boca Raton, Florida, p. 233-265.

Thieler, E. R., and Young, R. S., 1991, Quantitative evaluation of geomorphological changes in South Carolina after Hurricane Hugo, in Finkl, C. W., and Pilkey, O.H., Impacts of Hurricane Hugo: September 10-22, 1989: Journal of Coastal Research Special Issue 8, p. 187-200.

Titus, J. G., ed., 1988, Greenhouse effect, sea level rise and coastal wetlands: Environmental Protection Agency, EPA-230-05-86-013, Washington, D. C., 152 p.

Wells, J. T., and Coleman, J. M., 1987, Wetland loss and the subdelta life cycle: Estuarine, Coastal, and Shelf Science, v. 25, 111-125.

White, W. A., Calnan, T. R., Morton, R. A., Kimble, T. G., Littleton, T. G., McGowen, J. H., Nance, H. S., and Schmedes, K. E., 1985, Submerged lands of Texas, Galveston-Houston area: Sediments, geochemistry, benthic invertebrates, and associated wetlands: The University of Texas at Austin, Bureau of Economic Geology, 145 p.

White, W. A., and Morton, R. A., 1997, Wetland losses related to fault movement and hydrocarbon production, southeastern Texas coast: Journal of Coastal Research, v. 13, p. 1305-1320. 